https://doi.org/10.18485/iipe_postkovid.2021.ch3

\title{
KLIMATSKE PROMENE - GLOBALNI ČINILAC MEĐUNARODNIH ODNOSA I LIDERSKE AMBICIJE EVROPSKE UNIJE
}

\begin{abstract}
Dragoljub TODIĆ ${ }^{1}$
Apstrakt: U radu se razmatra hipoteza da Evropska unija (EU) ima lidersku ulogu u oblasti klimatskih promena. Opšti kontekst istraživanja određen je značajem i složenim karakterom klimatskih promena, kao i njihovim (mogućim) uticajem na međunarodne odnose. Pri tome se polazi od neophodnosti uvažavanja međuzavisnosti tzv. unutrašnjih i tzv. spoljnih dimenzija (aspekata) aktivnosti u oblasti životne sredine i klimatskih promena. Analiziraju se postojeći podaci o doprinosu EU ukupnim emisijama gasova sa efektom staklene bašte (GHG). Porede se podaci za EU sa podacima za države najveće GHG emitere. U drugom delu rada daje se prikaz ključnih odgovora EU na izazove klimatskih promena. Ukazuje se na najznačajnije elemente politike EU u oblasti klimatskih promena na unutrašnjem planu (čiji je opšti cilj tzv. klimatska neutralnost koja treba da se postigne do 2050. godine). $U$ delu koji se odnosi na aktivnosti EU na međunarodnom nivou, naglašava se značaj ostvarivanja ciljeva Sporazuma iz Pariza (u delu koji se odnosi na mogućnosti smanjenja GHG emisija). Porede se ciljevi smanjenja emisija koje je preuzela EU sa ciljevima koje su preuzele države najveći GHG emiteri. U zaključku se konstatuje da pitanje "globalnog” karaktera klimatskih promena, kao činioca savremenih međunarodnih odnosa, zaslužuje znatno detaljniju analizu. Istovremeno, jasno je (uz određene rezerve metodološkog karaktera) da klimatske promene zauzimaju značajno mesto u aktivnostima EU i da stavovi o tzv. liderskoj ulozi EU nisu bez osnova. Ciljevi koji se odnose na tzv. klimatsku neutralnost (2050), predvodnička uloga u sprovođenju međunarodnih ugovora i pomoć drugim državama, idu u prilog potvrde stava o liderskoj ulozi ove organizacije. Međutim, ukupni rezultati liderskih aktivnosti EU ostaju u senci globalnog karaktera problema,
\end{abstract}

\footnotetext{
${ }^{1}$ Redovni profesor, Institut za međunarodnu politiku i privredu, Beograd, e-mail: dtodic@ymail.com.

Rad je nastao u okviru naučnoistraživačkog projekta „Srbija i izazovi u međunarodnim odnosima 2021. godine”, koji finansira Ministarstvo prosvete, nauke i tehnološkog razvoja Republike Srbije, a realizuje Institut za međunarodnu politiku i privredu tokom 2021. godine.
} 
kao i potrebe da u njegovom rešavanju učestvuju drugi subjekti, a naročito najveći GHG emiteri.

Ključne reči: EU, klimatske promene, Kjoto protokol, Sporazum iz Pariza, spoljna politika EU u oblasti klimatskih promena, GHG emisije, klimatska neutralnost.

\section{Opšti kontekst i metodološke napomene}

Mesto koje klimatske promene imaju u savremenim međunarodnim odnosima uslovljeno je većim brojem činilaca, među kojima su verovatno najočigledniji složena priroda problema, globalni karakter, visok nivo međuzavisnosti i potreba za učešćem svih subjekata u njegovom rešavanju. ${ }^{2} U$ zavisnosti od primenjene metodologije moguće su različite procene relevantnosti klimatskih promena za međunarodne odnose. ${ }^{3}$ Globalnost problema predstavlja manifestaciju sistemskog karaktera, zbog čega se može reći da ne postoji region koji nije (ili neće biti) pod uticajem onoga što se

\footnotetext{
${ }^{2}$ Način na koji se uzroci i posledice klimatskih promena danas razumeju ukazuje na „klimu” kao složen i "dinamičan sistem” koji je rezultat kombinovane interakcije različitih delova Zemlje (jednih sa drugima i sa Suncem). Klimatski sistem uključuje atmosferu, okean (hidrosfera), lednike, kopnene ledene pokrivače i morski led (zajednički poznati kao kriosfera), živu biomasu (biosfera) i čvrste delove Zemlje (litosfera). Za šire videti: Edmond A. Mathez and Jason Smerdon, Climate Change: The Science of Global Warming and Our Energy Future, Columbia University Press, New York, 2018. Iz ovakog određenja „klimatskog sistema", koji je svoje mesto našao i u članu 1.3. Okvirne konvencije UN o promeni klime (u daljem tekstu: UNFCCC), proističu najmanje dve ključne karakteristike: jedinstvenost i sistemski karakter, kao i opštost (globalnost) pitanja. Za tekst UNFCCC videti: SI. list SRJ Međunarodni ugovori, br. 2/1997, ili https://treaties.un.org/Pages/ViewDetailsIII.aspx?src= TREATY\&mtdsg_no=XXVII-7\&chapter=27\&Temp=mtdsg3\&clang=_en, 3/7/2021.

${ }^{3}$ Tako, na primer, neki autori procenjuju da mesto koje klimatske promene imaju u međunarodnim odnosima nije zadovoljavajuće. lako, politički lideri klimatske probleme opisuju kao „najveći izazov našeg vremena, one igraju samo marginalnu ulogu u spoljnoj politici većine država". Slično je i u načnoj literaturi koja se bavi međunarodnim odnosima. Ole Jacob Sending, Indra Øverland, and Thomas Boe Hornburg, "Climate Change and International Relations: A five-pronged research agenda", Journal of International Affairs, vol. 73 , no. 1, pp. 183-193. Autori navode podatak da samo 0,77\% članaka u pet vodećih časopisa o međunarodnim odnosima (između 2015. i 2019. godine) govori o klimatskim promenama. Istovremeno, predlažu pet širokih područja na kojima je potrebno bolje razumeti kako će klimatske promene preoblikovati svetsku politiku. To su: suverenitet, bezbednost, status i ugled, norme i koalicije te geopolitika energije.
} 
označava pojmom „klimatske promene". ${ }^{4}$ Izgleda da bi se zajednički imenitelj globalnih dimenzija klimatskih promena mogao, najvećim delom i posredstvom različitih činilaca (poremećaji u međunarodnoj privredi, proizvodnja hrane, migracije, zdravstveni problemi itd.), povezati sa bezbednosnim izazovima. ${ }^{5}$ „Klimatski rizici”, iako u osnovi nejasan pojam, poprimaju centralno mesto u delu akademskih rasprava i aktivnosti dela najznačajnijih međunarodnih organizacija. Odgovornost za stanje u oblasti klimatskih promena predstavlja jedan od nosećih stubova opšteg okvira rasprave čije tragove nalazimo u ogromnom delu savremene literature. ${ }^{6}$ Otuda širina sistemskih pitanja, koja se povezuju sa uzrocima i posledicama klimatskih promena, uslovljava i metodološke probleme u vezi sa određivanjem granica istraživanja. ${ }^{7}$

U takvim okolnostima, način na koji klimatske promene utiču na odnos pojedinih (teritorijalno i politički zasebnih) delova Planete, kako oni definišu svoj

${ }^{4}$ Za dalju raspravu neophodno je imati u vidu i definiciju pojma „promena klime” budući da i oko toga postoje različita tumačenja. Iz definicije koja je ponuđena u UNFCCC može se razaznati nekoliko elemenata: 1 ) da se klimatske promene vezuju isključivo za one koje su izazvane ljudskim aktivnostima, 2) da te ljudske aktivnosti izazivaju promene u sastavu globalne atmosfere, i 3) da su te klimatske promene "superponirane na prirodna kolebanja klime" koje su osmotrene tokom uporedivih vremenskih perioda (tačka 2). Za potrebe ovog članka ne ulazi se u posebnu raspravu o pojmu „klimatske promene”, već se za osnovu uzimaju elementi definicije iz UNFCC čiji je Evropska unija (EU) član. Ovome prilagođena definicija služi i kao osnov za aktivnosti „Eurostata” (tela koje se u okviru EU bavi statistikom), i obuhvata sledeće elemente: promene klimatskih obrazaca usled ljudskih aktivnosti; one nadilaze prirodne varijabilnosti klime; uzroci promena leže u gasovima sa efektom staklene bašte (GHG) koji se emituju u atmosferu; među pokretačima tih emisija su sagorevanje fosilnih goriva, industrijski procesi, stočarstvo i obrada otpada. https://ec.europa.eu/eurostat/web/climate-change, 25/06/2021.

${ }^{5}$ Jon Barnett, "Global environmental change II: Political economies of vulnerability to climate change", Progress in Human Geography, vol. 44, no. 6, 2020, pp. 1172-1184.

${ }^{6}$ Ovo pitanje se obično stavlja u kontekst rasprave o primeni principa „zajedničke ali izdiferencirane odgovornosti" (koji je eksplicitno formulisan u članu 4 UNFCCC) i tzv. klimatske pravde, zatim odnosa između razvijenih i nerazvijenih država, raspodeli troškova za štete koje nastaju usled klimatskih promena, rešavanju sporova, ljudskim pravima itd. Za šire videti: Dragoljub Todić, ,' Klimatska pravda' i Pariski sporazum o klimi u svetlu ciljeva smanjenja emisija gasova sa efektom staklene bašte", Međunarodni problemi, vol. 52, br. 3, 2020, str. 467-498.

7 Za šire videti: Dragoljub Todić, „,Gde su granice prava klimatskih promena?”, Zbornik radova Pravnog fakulteta u Nišu, vol. 83, 2019, str. 41-59. 
odgovor na izazove u ovoj oblasti, kakvi su rezultati takvih aktivnosti itd., predstavlja pitanja na koje bi odgovor mogao da se potraži na različite načine. U zavisnosti od primenjene metodologije, istraživanje odnosa pojedinih država ili grupa država (organizovanih u regionalne grupacije i organizacije kakva je EU), mogao bi voditi različitim zaključcima. ${ }^{8}$ Pri tome bi trebalo voditi računa o prelivanju efekata mera koje se preduzimaju na unutrašnjem planu (ili čija se prevashodna svrha odnosi na ostvarivanje ciljeva na unutrašnjem planu, u okviru države ili međunarodne organizacije), na međunarodni nivo (i obrnuto). ${ }^{9}$ Zapravo, prelivanje posledica aktivnosti, za koje se obično smatra da prevashodno imaju unutrašnji karakter, u međunarodne (van granica EU) očigledno je ako se pogledaju sadržaji nekih od tih aktivnosti (praćenje i izveštavanje o emisijama, trgovanje emisijama, raspodela tereta, emisije iz zemljišta, emisije iz sektora transporta, niskougljenične inovacije, ozonski omotač, fluorovani gasovi, prilagođavanje klimatskim promenama, finansiranje delovanja u oblasti klime). ${ }^{10}$

U ovom radu se ispituje uloga koju jedna regionalna organizacija ima u savremenoj politici i pravu klimatskih promena. Za jedinicu analize uzima se EU, tj. njena liderska uloga u ovoj oblasti. Polazi se od stava da nije moguće precizno razgraničiti veze između spoljnih dimenzija politike EU u oblasti klimatskih promena i politike ove organizacije na unutrašnjem planu. ${ }^{11}$ Traže se argumenti u prilog tezi o liderskoj poziciji EU u oblasti klimatskih promena kroz analizu

\footnotetext{
${ }^{8} \mathrm{U}$ detaljnijoj analizi morao bi da se uzme u obzir veći broj regionalnih specifičnosti koje su posledica (ili se očekuje da budu posledica) promene klime.

${ }^{9}$ Za šire videti: Paul G. Harris, "Bringing the In-Between Back in: Foreign Policy in Global Environmental Politics", Politics \& Policy, vol. 36, no. 6, 2008, p. 914-943. Lauri Peterson, "Domestic and international climate policies: complementarity or disparity?", International Environmental Agreements: Politics, Law and Economics, 26 June 2021. DOI: 10.1007/ s10784-021-09542-7.

${ }^{10} \mathrm{https}: / /$ ec.europa.eu/info/energy-climate-change-environment/topics/climate-change _en, 16/6/2021. Pitanje razgraničenja sa „,klasičnim” sadržajima spoljne politike ostaje van okriva rasprave i u terminologiji EU ovaj segment aktivnosti se najvećim delom označava formulacijom „saradnja sa državama ne-članicama EU i regionima”.

${ }^{11}$ Ove veze se eksplicitno naglašavaju u dokumentu Evropskog parlamenta posvećenom „klimatskoj diplomatiji”. U dokumentu se konstatuje da je „spoljnu ulogu EU kao lidera potrebno ... dopuniti snažnom unutarnjom klimatskom politikom." Obrazloženje Predloga Rezolucije Evropskog parlamenta o klimatskoj diplomatiji (2018).
} 
doprinosa EU ukupnim GHG emisijama i obaveza koje je EU preuzela u okviru Sporazuma iz Pariza u delu koji se odnosi na smanjenje GHG emisija. ${ }^{12}$

\section{Klimatske promene i EU}

\section{Liderske ambicije - teorijske napomene}

U delu stručne i naučne literature uloga EU se razmatra u kontekstu tzv. liderske uloge koju ova organizacija ima (ili se tvrdi da ima) u oblasti klimatskih promena. Pripisivanje EU liderske uloge zasnovano je na analizima dosadašnjeg ponašanja ove organizacije (i država članica organizacije pojedinačno), od kako su klimatske promene postale predmet aktivnosti na globalnom nivou. ${ }^{13} \mathrm{Od}$ usvajanja UNFCCC (1992) pokrenuti su značajni organizacioni, tehnički, ljudski itd. kapaciteti u pravcu izgradnje instrumenata za usporavanje (borbu protiv) klimatskih promena i adaptaciju na klimatske promene. Naravno, pitanje „liderstva” EU zaslužuje znatno detaljniju analizu i snažno zavisi od primenjene metodologije. ${ }^{14}$ Sam koncept „vodstva” („liderstva”) nije jasan i može da znači različite stvari. Neki povezuju vodstvo sa ishodima, dok drugi više naglašavaju osobine vođe - poput ambicije, preduzimanja inicijativa i „vođenja primera”. Kao rezultat toga, procene vodstva EU o klimatskim promenama mogli bi da se

"European Parliment Resolution on Climate Diplomacy", Report, European Parliament, Explanatory Statement, 26.6.2018. Internet: https://www.europarl.europa.eu/doceo/ document/A-8-2018-0221_EN.html, 28/06/2021.

12 Van razmatranja (zbog ograničenog prostora) ostaju drugi parametri čijom analizom bi se zaključci verovatno učinili pouzdanijim. Npr. intenzitet GHG emisija (emisije u odnosu na GDP), analiza doprinosa pojedinih privrednih sektora, uticaj kumulativnih emisija itd.).

${ }^{13}$ Sebastian Oberthür \& Claire Roche Kelly, "EU Leadership in International Climate Policy: Achievements and Challenges", The International Spectator, vol. 43, no. 3, 2008, pp. 35-50.

${ }^{14} \mathrm{Npr}$. CCPI (Climate Change Performance Index) procenjuje 57 zemalja i Evropsku uniju, koje zajedno generišu više od $90 \%$ globalnih GHG emisij. Koristeći standardizirane kriterije, CCPI razmatra četiri kategorije, sa 14 pokazatelja: GHG emisije (40\% ukupne ocene), obnovljiva energija (20\%), upotreba energije (20\%) i klimatska politika (20\%). Jedinstveni odjeljak o klimatskoj politici CCPI ocenjuje napredak zemalja u sprovođenju politika koje se sprovode radi postizanja ciljeva Sporazuma iz Pariza. Videti: https://ccpi.org/ country/eu/, 16/6/2021. Prema metodologiji ove organizacije EU (kao organizacija) se nalazi na 16. mestu. Redosled velikih GHG emitera izgleda ovako: Indija (10), Brazil (25), Kina (33), Japan (45), Ruska Federacija (52), SAD (61). https://ccpi.org/ranking/, 16/6/2021. 
razlikuju. ${ }^{15}$ Jedan od osnova za različit pristup mogu predstavljati i procene okolnosti razvoja EU, kao i dinamika promena u rešavanju problema klimatskih promena na globalnom nivou. ${ }^{16}$ Literatura o „liderstvu i pionirima u ekološkoj i klimatskoj politici" u početku je uglavnom bila fokusirana na države. ${ }^{17}$ Međutim, nedržavni akteri sve su češće identifikovani kao sposobni da pokažu liderstvo u oblasti klimatskih promena. Tradicionalno se analiziralo kako se upravljanje međunarodnim klimatskim promenama odvija unutar struktura na više nivoa, unutar kojih „Vođe” (i „pioniri”) igraju središnju ulogu. Kasnije, posebno od usvajanja Sporazuma iz Pariza 2015. godine, kojim je napušten pristup ciljeva „odozgo prema dole” (koji je bio karakterističan za Kjoto protokol iz 1997. godine) u korist pristupa „odozdo prema gore” s nacionalnim obećanjima (tj. nacionalno određenim doprinosima), čini se da je međunarodno upravljanje klimom postalo policentričnije. ${ }^{18}$ Zavisno od nivoa njihovih unutrašnjih i spoljnih ambicija, države mogu idealno zauzeti četiri pozicije koje Vajering (Wiering) et al. označavaju kao „zaostajanje”, „simboličke vođe”, „pioniri” ili „potiskivači” (oni koji guraju)" ${ }^{19}$ Delovanje država članica može se ocenjivati i uz pomoć različitih

${ }^{15}$ Sevasti-Eleni Vezirgiannidou, "European Union foreign policy and the global climate regime, By Simon Schunz", International Affairs, vol. 91, no. 1, January 2015, pp. 182-183.

${ }^{16}$ Za šire videti: Thomas Diez. "Setting the limits: Discourse and EU foreign policy", Cooperation and Conflict, vol. 49, no. 3, 2014, p. 320. Lisanne Groen, Arne Niemann, "The European Union at the Copenhagen climate negotiations: A case of contested EU actorness and effectiveness", International Relations, First Published, September 2, 2013, p. 309. Bertil Kilian and Ole Elgström, "Still a green leader? The European Union's role in international climate negotiations", Cooperation and Conflict, vol. 45, no. 3, 2010, p. 255.

${ }^{17}$ Rüdiger K. W. Wurzel, Duncan Liefferink \& Diarmuid Torney, "Pioneers, leaders and followers in multilevel and polycentric climate governance", Environmental Politics, vol. 28, no. 1, 2019, p. 4.

${ }^{18}$ Andrew Jordan, Dave Huitema, Harro Van Asselt, Johanna Forster, (eds.), Governing Climate Change, Policyentricity in Action?, Cambridge University Press, 2018, p. 135. Runhaar et al. razmatraju ulogu kompanija, lidera u oblasti životne sredine, nudeći tipologiju lidera i predloge za unapređenje podrške liderima. Hens Runhaar, Casper Tigchelaar, and Walter Vermeulen, Environmental leaders: making a difference. A typology of environmental leaders and recommendations for a differentiated policy approach, Business Strategy and the Environment, vol. 17, no. 4, 2008, pp. 160-178.

${ }_{19}$ Mark Wiering, Duncan Liefferink, Barbara Beijen, "The internal and external face of Dutch environmental policy: A case of fading environmental leadership?", Environmental Science \& Policy, vol. 81, 2018, pp. 18-25. 
vrsta vodstva: strukturnog, kognitivnog, preduzetničkog i uzornog. Autori, na primeru Holandije, ukazuju na značaj nesklada između „unutrašnjeg i spoljnog lica zemlje", koji je nastao usled slabih rezultata u sprovođenju propisa EU u oblasti kvalitetva vode, kvaliteta vazduha, očuvanja prirode i zagađivanja zemljišta nitratima iz poljoprivrede.

\section{Doprinos EU ukupnim GHG emisijama}

Udeo u ukupnim GHG emisijama obično se uzima kao jedan od početnih kriterijuma kojima se određuju značaj pojedinih država ili regiona u ostvarivanju ciljeva u međunarodnij zajednici. Prema podacima Svetske banke ukupne svetske GHG emisije u 2018. godini su iznosile 45,873,850 (Kt CO2 ekvivalent). Na čelu liste najvećih GHG emitera 2018. godine je bila Kina, da bi EU (kao celina bila na trećem mestu, nakon SAD, a ispred Indije i Rusije (Tabela 1). ${ }^{20} \mathrm{U}$ momentu potpisivanja UNFCCC (pre skoro trideset godina) na čelu te liste su bile SAD, sa EU na drugom mestu i Kinom na trećem mestu. Iz Tabele se vidi da EU beleži kontinuirano smanjivanje ukupne količine emisija od 1992. godine do danas (od 4,334,350 do 3,567,090 Kt CO2 ekvivalent), za razliku od SAD čije se ukupne emisije uz određene oscilacije u osnovi održavaju na približno istom nivou (u rasponu od 6,000,620 do 6,861,150) i Ruske Federacije (u rasponu od 2,919,159 do $2,543,400) .{ }^{21}$ Na drugom kraju su ukupne emisije Kine koje se konstatno povećavaju, kao emisije Indije. Razlika je u tome što su emisije Kine u ovom periodu povećane četiri puta, a Indije nešto više nego duplirane.

\footnotetext{
20 Unutar EU najveće ukupne emisije imaju Nemačka (806,090), Francuska (423,350), Italija $(399,600)$, Poljska $(389,650)$, Španija $(326,940)$ itd.

${ }^{21}$ „Annual European Union greenhouse gas inventory 1990-2019 and inventory report 2021", Submission to the UNFCCC Secretariat, EEA/PUBL/2021/066, European Environment Agency, 27 May 2021, p. iii.
} 
Tabela 1: Ukupne GHG emisije (Kt CO2 ekvivalent) - EU22

\begin{tabular}{|c|c|c|c|c|c|c|c|c|}
\hline & 2018 & 2015 & 2010 & 2000 & 1997 & 1992 & 1979 & 1970 \\
\hline Kina & $12,355,240$ & $11,859,290$ & $10,203,820$ & $4,597,430$ & $4,311,650$ & $3,503,100$ & $2,773,803$ & $1,873,971$ \\
\hline SAD & $6,023,620$ & $6,003,650$ & $6,442,580$ & $6,861,150$ & $6,675,570$ & $6,000,620$ & $6,135,462$ & $5,400,503$ \\
\hline EU & $\underline{3,567,090}$ & $\underline{3,621,560}$ & $3,960,810$ & $4,209,000$ & $4,324,350$ & $4,334,100$ & $5,508,796.9$ & $4,595,428$ \\
\hline Indija & $3,374,990$ & $3,063,650$ & $2,564,1530$ & $1,717,560$ & $1,567,730$ & $1,313,710$ & $1,678,280$ & 746,498 \\
\hline Rusija & $2,543,400$ & $2,475,690$ & $2,454,000$ & $2,194,340$ & $2,122,510$ & $2,919,150$ & $2,964,555$ & $2,240,872$ \\
\hline Japan & $1,186,770$ & $1,265,070$ & $1,228,240$ & $1,274,300$ & $1,279,530$ & $1,212,810$ & $1,159,212$ & 941,132 \\
\hline Brazil & $1,032,640$ & $1,082,700$ & 986,440 & 765,600 & 713,090 & 631,150 & $1,415,028$ & $1,260,982$ \\
\hline Svet & & & & & & & & \\
\hline
\end{tabular}

Izvor za EU: https://data.worldbank.org/indicator/EN.ATM.GHGT.KT.CE?locations=EU. 30/6/ 2021. Izvor za Kinu: https://data.worldbank.org/indicator/EN.ATM.GHGT.KT.CE?locations= CN. 30/6/2021. Izvor za SAD: https://data.worldbank.org/indicator/EN.ATM.GHGT.KT.CE? locations=CN-US. 30/6/2021. Izvor za Indiju: https://data.worldbank.org/indicator/EN . ATM.GHGT.KT.CE?locations=IN. 30/6/2021. Izvor za Rusku Federaciju: https://data.world bank.org/indicator/EN.ATM.GHGT.KT.CE?locations=RU. 30/6/2021.

Međutim, kada se pogledaju podaci o emisijama p/c otvara se mogućnost dodatnih korekcija u zaključcima. Na listi pet najvećih emitera (u ukupnim emisijama) EU se nalazi na četvrtom mestu sa konstatnom tendencijom pada (od 8.0 u 1992. godini do 6.4 u 2018). ${ }^{23}$ Smanjenje CO2 emisija p/c imaju i SAD

22 U Tabeli 1 prikazani su podaci za 2018. godinu (poslednja godina za koju postoje podaci), 2015. godinu (godina kada je zaključen Sporazum iz Pariza), 1997. godinu (godina kada je zaključen Kjoto protokol) i 1992. godinu (godina kada je zaključena UNFCCC), 1979. (godina kada je zaključena Konvencija o prekograničnom prenosu zagađujućih materija na velike udaljenosti). Osim toga, a radi praćenja kontinuiteta, navedni su i podaci za 2000. i 2010. godinu, kao i za 1970. godinu (prvu godinu za koju postoje podaci).

${ }^{23}$ Unutar EU u grupi država koje imaju najveće emisije p/c (znatno iznad svetskog proseka koji je 4.5) nalaze se Luksemburg (15.3), Estonija (12.1), Češka (9.6), Holandija (8.8), Nemačka (8.6), Poljska (8.2), Belgija (8.2). U grupi država koje imaju najmanje emisije nalaze se Malta (3.2), Švedska (3.5), Rumunija (3.8), Litvanija (4.1), Hrvatska (4.1), Francuska (4.6). 
i Rusija. S druge strane, konstatni rast se beleži u slučaju Kine (sa 2.01992 . godine do 7.4 u 2018. godini) i Indije (sa 0.6 u 1992. godini do 1.8 u 2018. godini). ${ }^{24}$

\section{Odgovor EU i Sporazum iz Pariza}

Odgovor EU na izazove u oblasti klimatskih promena može da se prati od prvih aktivnosti koje je međunarodna zajednica preduzimala u ovoj oblasti i trenutno je formulisan $u$ nekoliko strateških/planskih dokumenata ove organizacije. ${ }^{25}$ Procenjuje se da su najave EU, kojima je cilj da se postigne neto nulta GHG emisija do 2050. godine, pozitivni signali. ${ }^{26}$ Kada se radi o međunarodnim aktivnostima, EU svoje delovanje stavlja u okvire obaveza koje je ova organizacija preuzela na međunarodnom planu, tj. u okviru režima koji je ustanovljen UNFCCC, Kjoto protokolom i Sporazumom iz Pariza. ${ }^{27}$ Jedan značajan aspekt delovanja EU obuhvata finansiranje aktivnosti u oblasti klimatskih promena na međunarodnom planu. ${ }^{28}$ lako se vode različite rasprave u vezi sa konceptom i ciljevima koje je ustanovio Sporazum iz Pariza, to ne bi trebalo da utiče na činjenicu da on trenutno predstavlja neku vrstu okosnice savremene politike i prava u oblasti klimatskih promena. Ostvarivost ciljeva koji su propisani Sporazumom iz Pariza predmet je, takođe, širokih rasprava kojima se zadire u

${ }^{24}$ Izvor: The World Bank, CO2 emissions (metric tons per capita) - European Union, Internet: https://data.worldbank.org/indicator/EN.ATM.CO2E.PC?locations=EU, 3/7/2021.

${ }^{25}$ Evropski zeleni plan predstavlja najširu osnovu i podrazumeva, između ostalog, i donošenje prvog evropskog propisa o klimi (Uredbe), s ciljem postizanja tzv. klimatske neutralnosti do 2050. godine. Internet: https://ec.europa.eu/clima/policies/eu-climate-action_en, 4/7/2021.

${ }^{26}$ Climate Change Performance Index, EU, Internet: https://ccpi.org/country/eu/, 4/7/2021.

${ }^{27}$ Za sistematizovan pregled aktivnosti EU videti kod Beatriz Pérez de las Heras, "From Kyoto to Paris: the European Union's contribution to a new world climate order", Revista Catalana de Dret Ambiental, [en línia], vol. 9, no. 1, 2018, pp. 1-26. EU je članica Sporazuma iz Pariza od 5. oktobra 2016. godine. https://treaties.un.org/Pages/View Details.aspx?src=TREATY\& mtdsg_no=XXVII-7-d\&chapter=27\&clang=_en, 11/2/2021. Za tekst Sporazuma videti: "Sporazum iz Pariza", Sl. glasnik RS - Međunarodni ugovori, br. 4/2017. ili https://treaties. un.org/doc/Treaties/2016/02/20160215\%2006-03\%20PM/Ch_XXVII-7-d.pdf, 16/6/2021.

${ }^{28} \mathrm{EU}$, njene države članice i Evropska investiciona banka (zajedno) najveći su kontributori javnih finansija za aktivnosti u oblasti klimatskih promena u zemljama u razvoju sa 20,4 milijarde u 2017. godini. "The EU: a leader in global climate finance", European Union, 2018, Internet: https://ec.europa.eu/clima/sites/default/files/docs/climate_finance_leaflet_en.pdf, 9/7/ 2021. Videti i: "The EU: a leader in global climate finance", European Union, 2018. https:// ec.europa.eu/clima/sites/default/files/docs/climate_finance_leaflet_en.pdf, 9/7/2021. 
koncepcijske osnove ovog međunarodnog ugovora. ${ }^{29}$ Smanjenje GHG emisija ima značaj jedne od centralnih obaveza koje proističu iz Sporazuma.

U prvom dokumenti koji se odnosi na "nacionalno utvrđene doprinose" (NDC), koji je EU podnela 2016. godine, ova organizacija se obavezala da će do 2030. godine smanjiti svoje GHG emisije „najmanje za 40\%”. ${ }^{30} \mathrm{U}$ ažuriranom dokumentu koji je podnet četiri godine kasnije, EU se obavezuju da do 2030. godine smanji neto domaće GHG emisije „za najmanje 55\%" u odnosu na 1990. godinu. ${ }^{31}$ Dugoročna strategija EU i država članica u oblasti razvoja niskih GHG emisija dostavljena je Sekretarijatu UNFCCC početkom 2020. godine. ${ }^{32}$ Promovisan je cilj Evropskog zelenog plana koji EU želi postići do 2050. godine i on se sastoji u „klimatskoj neutralnosti” koja znači stvaranje osnova za privredu sa nultom neto stopom GHG emisija. ${ }^{33}$ Da bi se to ostvarilo, tj. kako bi političke obaveze postale obavezujuće norme, predloženo je donošenje tzv. Evropskog propisa klimi. Predlog Uredbe o uspostavljanju okvira za postizanje klimatske neutralnosti i o izmeni Uredbe (EU) 2018/1999 (Europski propis o klimi) sačinjen je u martu 2020. godine. ${ }^{34}$ Iz Tabele 2 vidljivo je da je EU, u odnosu na države

${ }^{29}$ Marta Torres Gunfaus, Henri Waisman, "Assessing the adequacy of the global response to the Paris Agreement: Toward a full appraisal of climate ambition and action", Earth System Governance, vol. 8, 2021, pp. 1-5.

${ }^{30}$ Latvian Presidency on the Council of the European Union, Intended Nationally Determined Contribution of the EU and its Member States, Riga, 6 March 2015, Internet: https://www4.unfccc.int/sites/ndcstaging/PublishedDocuments/European\%20Union\%20 First/LV-03-06-EU\%20INDC(Archived).pdf, 2/7/2021.

${ }^{31}$ The update of the nationally determined contribution of the European Union and its Member States, Berlin, 17 December 2020, Internet: https://www4.unfccc.int/sites/ ndcstaging/PublishedDocuments/European\%20Union\%20First/EU_NDC_Submission_Dec ember\%202020.pdf, 2/7/2021.

${ }^{32}$ Croatian Presidency of the Council of the Europena Union, Long-term low greenhouse gas emission development strategy of the European Union and its Member States, Internet: https://unfccc.int/sites/default/files/resource/HR-03-06-2020\%20EU\%20Submission\%20on\%20Long\%20term\%20strategy.pdf, 2/7/2021.

${ }^{33}$ https://ec.europa.eu/clima/policies/strategies/2050_en, 2/7/2021.

34 "Proposal for a Regulation of the European Parliament and of the Council establishing the framework for achieving climate neutrality and amending Regulation (EU) 2018/1999 (European Climate Law)", COM/2020/80 final, European Commission, Brussels, 4.3.2020, Internet: https://eur-lex.europa.eu/legal-content/EN/TXT/?qid=1588581905912\&uri= CELEX:52020PC0080, 2/7/2021. 
najveće GHG emitere, na najjasniji način preuzela najveću obavezu smanjenja GHG emisija i to najmanje $55 \%$ do 2030 . godine. ${ }^{35}$

Tabela 2: Obaveze smanjenja GHG emisija EU i država najvećih emitera

\begin{tabular}{|c|l|c|}
\hline Kina & $\begin{array}{l}\text { Prvi izveštaj (2016) } \\
\text { Postići maksimum emisije ugljen-dioksida oko 2030. } \\
\text { gDP za 60\% do 65\% u odnosu na nivo iz 2005. } \\
\text { godine; Povećati udeo nefosilnih goriva u primarnoj } \\
\text { potrošnji energije na oko 20\% .... }\end{array}$ & $\begin{array}{c}\text { Drugi izveštaj } \\
\text { (2020, 2021-SAD) }\end{array}$ \\
\hline SAD & Smanjenje 26-28\% ispod nivoa 2005 ${ }^{37 .}$ & $\begin{array}{l}\text { Smanjenje neto emisije za } \\
50-52 \% \text { ispod nivoa iz 2005. } \\
\text { u 2030. godini. }{ }^{38}\end{array}$ \\
\hline
\end{tabular}

${ }^{35} \mathrm{U}$ tabeli 2 prikazani su ciljevi koje su EU i države članice formulisale i dostavile Sekretarijatu UNFCCC, kao odgovor na pitanje iz Upitnika koje se odnosi na „nameravane nacionalno određene doprinose", tj. numerički izražene planirane iznose smanjenja emisija. Naravno, u detaljnijoj analizi (koja prevazilazi okvire ovog rada), trebalo bi uzeti u obzir i odgovore na druga pitanja, tj. celinu sadržaja dokumenata koje su članice Sporazuma iz Pariza dostavile.

36 "China's intended nationally determined contribution: Enhanced Action on Climate Change", Department of Climate Change, National Development \& Reform Commission of China, Beijing, 30 June 2015. Internet: https://www4.unfccc.int/sites/ndcstaging/ Published Documents/China\%20First/China\%27s\%20First\%20NDC\%20Submission.pdf, 9/7/2021, p.5.

37 "The United States, intended nationally determined contribution", 3/9/2016, Internet: https://www4.unfccc.int/sites/ndcstaging/PublishedDocuments/United\%20States\% 20of\%20America\%20First/United\%20States\%20NDC\%20April\%2021\%202021\%20Final.p df, 9/7/2021, p.3.

38 "Nationally Determined Contribution Reducing Greenhouse Gases in the United States: A 2030 Emissions Target", The United States of America, 22/4/2021 (After rejoining the Paris Agreement), Internet: https://www4.unfccc.int/sites/ndcstaging/PublishedDocuments /United\%20States\%20of\%20America\%20First/United\%20States\%20NDC\%20April \%2021\%202021\%20Final.pdf, 11/7/2021, p. 6, 7. 


\begin{tabular}{|c|c|c|}
\hline & Prvi izveštaj (2016) & $\begin{array}{c}\text { Drugi izveštaj } \\
(2020,2021-\text { SAD) }\end{array}$ \\
\hline$\underline{E U}$ & $\begin{array}{l}\text { Smanjenje emisija za najmanje } 40 \% \text { do } 2030 . \\
\text { godine. }^{39}\end{array}$ & $\begin{array}{l}\text { Smanjenje neto emisija za } \\
\frac{\text { najmanje } 55 \% \text { GHG emisija }}{2030 . \text { u odnosu na } 1990 . .^{40}}\end{array}$ \\
\hline Indija & $\begin{array}{l}\text { Smanjiti intenzitet emisija GDP za 33-35\% do } \\
\text { 2030. u odnosu na nivo iz 2005. godine; Do } 2030 . \\
\text { godine postići oko } 40 \% \text { kumulativno instaliranog } \\
\text { kapaciteta električne energije iz izvora energije } \\
\text { koji se ne baziraju na fosilnim gorivima... }{ }^{41}\end{array}$ & - \\
\hline Rusija & $\begin{array}{l}\text { Smanjenje GHG emisija do } 2030 \text {. godine do } 70 \% \\
\text { u odnosu na nivo iz 1990. godine }{ }^{42}\end{array}$ & - \\
\hline
\end{tabular}

39 "Intended Nationally Determined Contribution of the EU and its Member States", Submission by Latvia and the European Commission on behalf of the European Union and its member states, Riga, 6 March 2015. Internet: https://www4.unfccc.int/sites/nd cstaging/Published Documents/European\%20Union\%20First/LV-03-06-EU\%20INDC (Archived).pdf, 9/7/2021, p. $1,2$.

40 "The update of the nationally determined contribution of the European Union and its Member States", Submission by Germany and the European Commission on behalf of the European Union and its member states, Internet: Berlin, 17. December 2020. https://www4.unfccc.int/sites/ndcstaging/PublishedDocuments/European\%20Union\%20 First/EU_NDC_Submission_December\%202020.pdf, 9/7/2021, p. 7.

${ }^{41}$ India's Intended Nationally Determinet Contribution: Working towards climate justice, Internet: https://www4.unfccc.int/sites/ndcstaging/PublishedDocuments/India\%20First /INDIA\%20INDC\%20TO\%20UNFCCC.pdf, 9/7/2021, p. 29.

42 „.... Uzimajući u obzir maksimalni mogući apsorpcijski kapacitet šuma i drugih ekosistema i podložno održivom i uravnoteženom društveno-ekonomskom razvoju Ruske Federacije". Nationally Determined Contribution of the Russion Federation, as part of the implementation of the Paris Agreement of December 12, 2015, Internet: https://www4.unfccc.int/sites/ndcstaging/PublishedDocuments/Russia\%20First/NDC_RF_ eng.pdf, 9/7/2021, p. 1. Izveštaj podnet 25.11.2020. godine. 


\begin{tabular}{|c|c|c|}
\hline & Prvi izveštaj (2016) & $\begin{array}{c}\text { Drugi izveštaj } \\
(2020,2021-S A D)\end{array}$ \\
\hline Japan & $\begin{array}{l}\text { Smanjenje od 26,0\% do fiskalne godine (FG) } 2030 . \\
\text { u odnosu na FG 2013. (smanjenje od 25,4\% u } \\
\text { odnosu na FG 2005) }\end{array}$ & $\begin{array}{l}\text { Smanjenje od } 26,0 \% \text { do } F G \\
\text { 2030. u odnosu na FG } 2013 \\
\text { (smanjenje od } 25,4 \% \text { u odnosu } \\
\text { na FG 2005)....44 }\end{array}$ \\
\hline Brazil & $\begin{array}{l}\text { Smanjenje GHG emisija za } 37 \% \text { u odnosu na nivo } \\
\text { iz 2005. godine. Do 2030. godine smanjiti emisije } \\
\text { za } 43 \% .{ }^{45}\end{array}$ & $\begin{array}{l}\text { Smanjenje GHG emisija za } 37 \% \\
\text { u odnosu na nivo iz } 2005 \\
\text { godine, odnosno za } 43 \% \text { do } \\
\text { 2030. godine. } 46\end{array}$ \\
\hline
\end{tabular}

\section{Zaključna razmatranja}

Na osnovu analize doprinosa EU ukupnim GHG emisijama, kao i formulisanih ciljeva smanjenja GHG emisija u okviru Sporazuma iz Pariza, može se tvrditi da „klimatske promene” predstavljaju činilac koji značajno utiče na aktivnostima EU. Liderska uloga EU ima osnova u do sada ostvarenim rezultatima smanjenja

\footnotetext{
${ }^{43}$ Submission of Japan's Intended Nationally Determined Contribution (INDC), 8/11/2016, Internet: https://www4.unfccc.int/sites/ndcstaging/PublishedDocuments/Japan\%20First /20150717_Japan\%27s\%20INDC.pdf, 9/7/2021, p. 3.

${ }^{44}$ Submission of Japan's Nationally Determined Contribution (NDC), Updated submission, 31/3/2020, Internet: https://www4.unfccc.int/sites/ndcstaging/PublishedDocuments/ Japan\%20First/SUBMISSION\%20OF\%20JAPAN\%27S\%20NATIONALLY\%20DETERMINED\%2 OCONTRIBUTION\%20(NDC).PDF, 9/7/2021, p. 6.

${ }^{45}$ Intended Nationally Determined Contribution towards achieving the objective of the United Nations Framework Convention on Climate Change, Feerative Republic of Brazil, 21/9/2016, Internet: https://www4.unfccc.int/sites/ndcstaging/PublishedDocuments /Brazil\%20First/BRAZIL\%20iNDC\%20english\%20FINAL.pdf, 9/7/2021, p. 1.

${ }^{46}$ Paris Agreement Brazil's Nationally Determined Contribution (NDC), 9/12/2020. https://www4.unfccc.int/sites/ndcstaging/PublishedDocuments/Brazil\%20First/Brazil\%20 First\%20NDC\%20(Updated\%20submission).pdf, 9/7/2021, p. 2.
} 
GHG emisija i ambicioznim ciljevima ove organizacije na unutrašnjem i međunarodnom planu. Bez obzira na mogućnost primene različite metodologije za ocenu uloge pojedinih država i regionalnih organizacija, potrebu detaljnije analize drugih pokazatelja i različite teorijske pristupe u tumačenju ",liderstva”, uloga EU se može okarakterisati vodećom. Naravno, ukupne rezultate aktivnosti koje se sprovode, odnosno koje su planirane u okviru EU, nije moguće procenjivati van globalnog konteksta i doprinosa drugih država, a pre svega najvećih GHG emitera. A uloga nekih od njih (čije ukupne GHG emisije nastavljaju da rastu ili ostaju na ranijem nivou bez jasnih naznaka o namerama smanjenja) u ovom trenutku deluje pomalo kontroverzno i zaslužuje posebnu analizu.

\section{Literatura}

\section{Monografije i članci}

Gunfaus Torres, Marta, Waisman, Henri, "Assessing the adequacy of the global response to the Paris Agreement: Toward a full appraisal of climate ambition and action", Earth System Governance, vol. 8, 2021, pp. 1-5.

Harris, G. Paul, "Bringing the In-Between Back in: Foreign Policy in Global Environmental Politics", Politics \& Policy, vol. 36, no. 6, 2008, pp. 914-943.

Jordan, Andrew, Huitema, Dave, Van Asselt, Harro, Forster, Johanna (eds.), Governing Climate Change, Policyentricity in Action?, Cambridge University Press, 2018.

Kilian, Bertil, Elgström, Ole, "Still a green leader? The European Union's role in international climate negotiations", Cooperation and Conflict, vol. 45, no. 3 , 2010, pp. 255-273.

Mathez, A. Edmond, Smerdon, Jason, Climate Change: The Science of Global Warming and Our Energy Future, Columbia University Press, New York, 2018.

Oberthür, Sebastian, Kelly, Claire, Roche, "EU Leadership in International Climate Policy: Achievements and Challenges", The International Spectator, vol. 43, no. 3, 2008, pp. 35-50, DOI: 10.1080/03932720802280594.

Pérez de las Heras, Beatriz, "From Kyoto to Paris: the European Union's contribution to a new world climate order", Revista Catalana de Dret Ambiental, [en línia], vol. 9, no 1, 2018, pp. 1-26. 
Peterson, Lauri, "Domestic and international climate policies: complementarity or disparity?", International Environmental Agreements: Politics, Law and Economics, 26 June 2021. DOI: 10.1007/s10784-021-09542-7.

Runhaar, Hens, Tigchelaar Casper, Vermeulen Walter, "Environmental leaders: making a difference. A typology of environmental leaders and recommendations for a differentiated policy approach", Business Strategy and the Environment, vol. 17, no. 4, 2008, pp.160-178. https://doi.org/ 10.1002/bse.520

Sending, Ole Jacob, Øverland Indra, and Hornburg Thomas Boe, "Climate Change and International Relations: A five-pronged research agenda", Journal of International Affairs, vol. 73, no. 1, pp. 183-193.

Todić, Dragoljub, „'Klimatska pravda' i Pariski sporazum o klimi u svetlu ciljeva smanjenja emisija gasova sa efektom staklene bašte", Međunarodni problemi, vol. 52, br. 3, 2020, str. 467-498.

Todić, Dragoljub, „Gde su granice prava klimatskih promena?”, Zbornik radova Pravnog fakulteta u Nišu, vol. 83, 2019, str. 41-59.

Vezirgiannidou, Sevasti-Eleni, "European Union foreign policy and the global climate regime. By Simon Schunz," International Affairs, vol. 91, no. 1, January 2015, pp. 182-183, https://doi.org/10.1111/1468-2346.12202.

Wiering, Mark, Liefferink, Duncan, Beijen, Barbara, "The internal and external face of Dutch environmental policy: A case of fading environmental leadership?", Environmental Science \& Policy, vol. 81, pp. 18-25.

Wurzel, Rüdiger K.W, Liefferink, Duncan, Torney, Diarmuid, "Pioneers, leaders and followers in multilevel and polycentric climate governance", Environmental Politics, vol. 28, no. 1, 2019, pp. 1-21, DOI: 10.1080/ 09644016.2019 .1522033$.

Dokumenti koji se odnose na „nacionalno određene doprinose smanjenju emisija gasova sa efektom staklene bašte"

(NDCs - "Nationally determined contributions")

1) Brazil:

Intended Nationally Determined Contribution towards achieving the objective of the United Nations Framework Convention on Climate Change, Feerative Republic of Brazil, 21/9/2016, Internet: https://www4.unfccc.int/sites/nd 
cstaging/PublishedDocuments/Brazil\%20First/BRAZIL\%20iNDC\%20english\% 20FINAL.pdf, 9/7/2021, p. 1.

Paris Agreement Brazil's Nationally Determined Contribution (NDC), 9/12/2020, Internet: https://www4.unfccc.int/sites/ndcstaging/PublishedDocuments /Brazil\%20First/Brazil\%20First\%20NDC\%20(Updated\%20submission).pdf, 9/7/2021, p. 2.

2) EU:

"Intended Nationally Determined Contribution of the EU and its Member States", Submission by Latvia and the European Commission on behalf of the European Union and its member states, Riga, 6 March 2015. Internet: https://www4.unfccc.int/sites/ndcstaging/PublishedDocuments/European \%20Union\%20First/LV-03-06-EU\%20INDC(Archived).pdf, 9/7/2021, p. 1, 2.

"The update of the nationally determined contribution of the European Union and its Member States", Submission by Germany and the European Commission on behalf of the European Union and its member states, Internet: Berlin, 17. December 2020. https://www4.unfccc.int/sites/ ndcstaging/PublishedDocuments/European\%20Union\%20First/EU_NDC_Su bmission_December\%202020.pdf, 9/7/2021, p. 7.

3) Indija:

India's Intended Nationally Determinet Contribution: Working towards climate justice, Internet: https://www4.unfccc.int/sites/ndcstaging/Published Documents/India\%20First/INDIA\%20INDC\%20TO\%20UNFCCC.pdf, 9/7/2021, p. 29.

Nationally Determined Contribution of the Russion Federation, as part of the implementation of the Paris Agreement of December 12, 2015, Internet: https://www4.unfccc.int/sites/ndcstaging/PublishedDocuments/Russia\%20 First/NDC_RF_eng.pdf, 9/7/2021, p. 1.

4) Japan:

Submission of Japan's Intended Nationally Determined Contribution (INDC), 8/11/2016, Internet: https://www4.unfccc.int/sites/ndcstaging/Published Documents/Japan\%20First/20150717_Japan\%27s\%20INDC.pdf, 9/7/2021, p. 3.

Submission of Japan's Nationally Determined Contribution (NDC), Updated submission, 31/3/2020, Internet: https://www4.unfccc.int/sites/ndcstaging/ 
PublishedDocuments/Japan\%20First/SUBMISSION\%20OF\%20JAPAN\%27S\% 20NATIONALLY\%20DETERMINED\%20CONTRIBUTION\%20(NDC).PDF, 9/7/2021, p. 6.

5) Kina:

"China' s intended nationally determined contribution: Enhanced Action on Climate Change", Department of Climate Change, National Development \& Reform Commission of China, Beijing, 30 June 2015. Internet: https://www4.unfccc.int/sites/ndcstaging/PublishedDocuments/China\%20F irst/China\%27s\%20First\%20NDC\%20Submission.pdf, 9/7/2021, p.5.

6) SAD:

"The United States, intended nationally determined contribution", 3/9/2016, Internet: https://www4.unfccc.int/sites/ndcstaging/PublishedDocuments/ United\%20States\%20of\%20America\%20First/United\%20States\%20NDC\%2 0April\%2021\%202021\%20Final.pdf, 9/7/2021, p.3.

"Nationally Determined Contribution Reducing Greenhouse Gases in the United States: A 2030 Emissions Target", The United States of America, 22/4/2021 (After rejoining the Paris Agreement), Internet: https://www4.unfccc.int/ sites/ndcstaging/PublishedDocuments/United\%20States\%20of\%20America \%20First/United\%20States\%20NDC\%20April\%2021\%202021\%20Final.pdf, 11/7/2021, p. 6,7 . 
Razvojni pravci Evropske unije nakon pandemije Kovid 19

\title{
CLIMATE CHANGE- A GLOBAL FACTOR IN INTERNATIONAL RELATIONS AND THE LEADERSHIP AMBITION OF THE EUROPEAN UNION
}

\begin{abstract}
The hypothesis that the European Union (EU) has a leading role in the field of climate change is considered. The general context of the research is determined by the significance and complex nature of global environmental problems, including climate change, as well as their (possible) impact on international relations. The starting point is the necessity of respecting the interdependence of the so-called internal and so-called external dimensions (aspects) of activities in the field of the environment and climate change. Existing data on the impact of climate change and the EU's contribution to total greenhouse gas (GHG) emissions are analysed. The data for the EU are compared with the data for the countries with the largest GHG emitters. The second part of the paper presents the key responses of the EU to the challenges of climate change. The most important elements of the EU policy in the field of climate change at the "internal" level are pointed out (whose general goal is the so-called climate neutrality, to be achieved by 2050). In the part related to EU activities at the international level, the importance of achieving the goals of the Paris Climate Agreement (in the part related to the possibilities of reducing GHG emissions) is especially emphasized. The emission reduction targets taken over by the EU are compared with the targets set by the countries with the highest GHG emissions. In conclusion, it is stated that the issue of the "global" character of climate change as a factor of modern international relations deserves a much more detailed analysis. At the same time, it is clear (with certain methodological reservations) that climate change occupies a significant place in EU activities, and that views on the so-called EU leadership role are not without foundation. The ambitions contained in the so-called climate neutrality (2050), a leading role in the implementation of international agreements and assistance to other states, support the position of the leadership role of this organization. However, the overall results of the EU's leadership activities remain in the shadow of the global character of the problem, as well as the need for other entities to participate in its solution, especially the largest GHG emitters.
\end{abstract}

Keywords: EU, climate change, Kyoto Protocol, Paris Climate Agreement, EU climate change foreign policy, GHG emission, climate neutrality. 